\title{
User generated content: the use of blogs for tourism organisations and tourism consumers
}

\author{
Gary Akehurst
}

Received: 24 November 2008/ Accepted: 25 November 2008/Published online: 11 December 2008

(C) The Author(s) 2008. This article is published with open access at Springerlink.com

\begin{abstract}
As the World Wide Web has developed considerable bargaining power has been transferred from suppliers to consumers; there is a real need to improve market intelligence and market research for private and public tourism organisations and facilitate timely consumer decision making. This article explores the development of user generated content and specifically the use of web logs or blogs. Tourism organisations cannot afford to ignore the development of user generated content, peer-to-peer web applications and virtual communities. A recent survey found that consumers trusted more websites with reviews than professional guides and travel agencies and far from being an irrelevance, blogs are often perceived to be more credible and trustworthy than traditional marketing communications. But there is a problem: given the sheer number of possibly relevant travel blogs there is a need to locate, extract and interpret blog content and this has proven so far to be time consuming, exhausting and costly, thus negating the relative value of the information obtained. A way forward may be the use of artificial intelligence and "opinion mining" or a blog visualisation system.
\end{abstract}

Keywords User generated content - Blogs · Tourism - Travel · Internet · Marketing

\section{Introduction}

Tourism organisations and enterprises, especially travel agencies, hotels and destination marketing organisations, have been seriously challenged by the rise of the internet but at the same time enormous opportunities have opened up. The internet has opened up and improved communications, distribution channels and

G. Akehurst ( $\square)$

RSM Erasmus University, Rotterdam, The Netherlands

e-mail: gakehurst@rsm.nl 
transactions in ways which could not have been imagined even at the beginning of the 2000s.

Tourists and travellers have at their command online resources which enable research of possible destinations, transportation, accommodation and leisure activities, and enable the purchase online of these products and services. This is nothing short of a consumer revolution which has effectively transferred much power from suppliers to consumers, and as the internet further expands and modifies into the Web 2.0 and the new grid, tourism organisations are well placed to take advantage of these new opportunities (Adam et al. 2007). It has also raised questions about marketing, distribution channels, improving business management and efficient marketing research in the tourism sector (Liu 2005).

Information is available on the internet but is that information accurate, up-todate and usable? Although we are surrounded by both copious internet and extrainternet information, how much is actually useful? Can it help tourists to make informed travel decisions and likewise enable tourist organisations at national, state and local levels to make important marketing decisions? The answer is clearly "yes" and tourism organisations were some of the first to utilise the resources of the internet, but we are seeing one area of significant internet innovation over the past 2 years in the widespread development of user generated content and peer-to-peer applications, variously known as Web 2.0, which would appear to have enormous potential for tourism organisations.

This article explores the development of user generated contents (UGC) and specifically the growing use of blogs in tourism. Web logs, shortened to "blogs," have been in existence since 1997, although it is only in recent years that their growth has been exponential. Such user generated content may provide tourism organisations and enterprises with valuable market intelligence and ongoing market research opportunities. On the other hand, such content may on occasions be of limited value, reflecting the incoherent, unstructured and random ramblings of individuals, which in another age might have been confined to the relative obscurity of a written diary. Such content may however be relatively difficult to locate and costly to do so.

The internet increases the effectiveness and efficiency of traditional marketing functions while the technology transforms marketing strategies enabling more efficiently planned and implemented promotion, distribution and pricing of goods and services. It opens up new global markets and international partnerships; it results in new business models that add customer value and increases profitability, and enables more effective segmentation, targeting and positioning strategies.

The current internet is still crude in capabilities and functionality and is still a rather chaotic test bed for companies, while consumers are learning new modes of interaction and consumption. The internet eases time and place constraints on consumers and no longer will products and services be offered primarily at the seller's convenience (power shifts from sellers to buyers) - anytime and anywhere purchasing and consumption is now common. As a consequence the expectations of consumers have been raised. There is no going back. Communication bandwidths will rapidly rise, and with it a greater use of movies, radio and television streaming; terminal equipment will become more powerful, smarter, easier to use, affordable, 
portable, cheaper and smaller while the cost of digital storage is falling rapidly. Once hardware and a truly effective telecommunications infrastructure is in place, an enormous range of services can be exchanged at nominal incremental cost, such as location-independent shopping and banking, computer-mediated education and training, online professional consultations and informational, entertainment and leisure services to name but a few services.

Successful marketing in this new environment involves "monocasting", "pointcasting" and "podcasting" of communications, with simultaneous mass customisation and personalisation of all marketing mix elements, a high degree of customer involvement and control, a more efficient utilisation of marketing resources with attempts to reduce customer alienation from misdirected marketing stimuli. Above all, there is increased pressure to deliver greater value and intense jostling among enterprises for the loyalties of "desirable" customers. As the power and pervasiveness of technologies grow consumers are in a unique, unaccustomed position, i.e., not passive-they have greater control of information flows between buyers and sellers. And they are now using this power. No industry can ignore this long-term shift in negotiating power.

Future consumers will be dramatically different from past and even present consumers-they will be more demanding, more time-driven, more information intensive and highly individualistic. In these radically different circumstances targeted interactive digital media allows organisations to mass customise messages, allowing user interaction and input. Consumers will in most cases have more information about product providers than providers will have about consumers, and consumers will largely dictate the timing and mode of communications-they will determine the time and place of resulting transactions and not the suppliers.

Up to now tourism marketing practice depended heavily on multiple intermediaries in the supply chain who added time and place utilities to the tourism product's functional quality. These intermediaries, such as travel agents and tour operators, provided broader and more convenient access to products for a wide range of customers and they served as informational conduits. Savvy consumers will make great use of information tools; they are knowledgeable and demanding drivers of tourism activities, and tourism enterprises and organisations will have to show greater respect for consumers (some of whom are showing increasing immunity to marketing hype). Finally, transactions will be in the context of a complex ongoing relationship revolving around lifestyle issues.

\section{Internet applications for tourism}

Tourism has been ranked as the foremost industry in terms of volume of online transactions (Werthner and Ricci 2004). For tourism organisations, both private and public, the internet has become one of the most important marketing communication channels (Wang and Fesenmaier 2006). Carson (2005) provides a summary of internet applications for tourism organisations and enterprises within an "online architecture" and proposes five important functions of the internet: communication, promotion, product distribution, management and research. This pre-supposes that 
enterprises would endeavour to learn and use these applications, enter partnerships and make effective use of the internet. Albert and Sanders (2003) talk about the four Ps marketing mix (of product, place, price and promotion) being enhanced by the four Cs of customer solution, cost, convenience and communication, while Newhagen and Rafaeli (1996) show that compared with other distribution and transaction channels the internet contains a truly huge amount of information which can be customised and personalised.

Carson (2005) raised issues about the barriers to effective internet usage including technical competence, variations in technology, adoption between government, enterprises and consumers, resistance to the innovations brought on by the internet, the access to IT infrastructure (especially broadband), the costs of using IT and government policies which might support but equally might discourage effective internet exploitation.

One area of extraordinary internet innovation over the past 2 years has been in user generated content and peer-to-peer applications variously known as Web 2.0 (O'Reilly 2005). We have seen the rise of social websites such as YouTube.com, Facebook, MySpace.com and Flickr.com. At first glance these sites lack any immediate relevance to tourism organisations-the content is often unstructured, indeed quirky and random, and the host organisation rarely manages content even when difficulties arise. Content is uploaded directly by users on to the website. Blogs provide primarily text information but increasingly video and audio files are uploaded. These blogs provide personal thoughts and commentaries on say a specific destination, personal travel stories and details of trips, and are often frequently updated and displayed in chronological order. Blogs tend to be interactive and readers post comments (Pan et al. 2007; Cobanoglu 2006; Kelleher and Miller 2006; Ellion 2007; Reactive 2007). The activities of blogs and bloggers have become known as the "blogosphere" (Carson 2008).

Specific tourism sites such as tripadvisor.com and travelpod.com enable consumers to exchange information, opinions and recommendations about destinations, tourism products and services, with sometimes diaries of travel experiences and ratings of a particular product or hotel. Other public travel blog sites specialising in hosting individual travel blogs include travelblog.org, travelpod.com, travelpost.com and yourtraveljournal.com (but these are by no means the only travel blogs currently available). These virtual communities have been in existence since the late 1990s (Lueg 2001; Schwabe and Prestipino 2006) and some studies have investigated the role and impact of such communities as useful tourist information providers (Schwabe and Prestipino 2006; Wang et al. 2002; Dellaert 2000; Laboy and Torchio 2007; Pan et al. 2007; Thraenhart 2007; Mack et al. 2008)). In addition, well-known travel guides provide web space to publish travel stories, for example, lonelyplanet.com and community.roughguides.com. Other Web 2.0 developments include RSS-feeds (media and content syndication), web forums, message boards, podcasting and vlogs (online videos).

By April 2007 there were apparently over 70 million blogs with around 120,000 new blogs created each day (Sifry 2007) and currently there are around 102 million blogs, with 175,000 new blogs added each day (http://technorati.com). A study undertaken by Compete Inc. has found UGC has an influence on around 
US $\$ 10$ billion p.a. in online travel bookings and over $20 \%$ of consumers rely on UGC when trip planning (Sarks 2007). It is clear that there is a higher perceived credibility of opinions expressed in UGC compared with traditional tourism information sources. This begs the question why? The answer probably lies in the need to consume tourism products before an evaluation can take place (Dellaert 2000; Rabanser and Ricci 2005; Senecal and Nantal 2004).So online reviews and word of mouth recommendations are a growing and important information source because of the perceived independence of the message source (Gitleson and Kerstetter 1994; Crotts 1999; Dellarocas 2003; Johnson and Kayne 2003; HennigThurau et al. 2004; Pan et al. 2007; Litvin et al. 2007). A recent UK survey found consumers trusted more sites with reviews than professional guides and travel agencies (eMarketer 2007). Similar research in Germany and Austria showed online customer ratings have high credibility with consumers (Österreich Werbung 2007) and a recent study by Gretzel et al. (2007) undertaken with tripadvisor.com users found that looking at other tourists' comments and travel blogs was the most popular online activity.

Recently, we have seen the development of "microblogging". Microblogging has taken the concept of blogging and compacts it. Conventional blogs can be of any length but microblogging is carried out usually by mobile phone text messages and is therefore currently restricted to just 140 characters (Beaumont 2008). Twitter is possibly the best known microblogging site and was launched in 2006 although other sites include Jaiku and Pownce. Users post messages to the site via the web or by text message and these "tweets" are forwarded onto their network of friends and contacts. Users share views on topics and news stories and ask for advice and help. For example, if I want to find a decent coffee shop in my home town of Southampton in the UK I ask my Twitter network or if I am thinking of going on holiday to Spain I ask my Twitter network. The advantage of this UGC is immediacy-I do not need to be at my computer to participate. Immediacy encourages participation and almost everyone has a mobile phone, and besides, it is more difficult to ignore a text message from a friend asking for views on something. Politicians have spotted this. In the USA, Hilary Clinton, John McCain and Barack Obama's promotion teams have been using Twitter to broadcast meeting schedules, election results and comments. In the UK 10 Downing Street, the Liberal Democrat party, Labour party and Conservative party are using Twitter as a supplement to existing political debates and stories. Microblogging is not however, confined to text messages. Tumblr and Hictu for example, enable photos and videos while MySay encourages users to leave a voice message. Twixtr enables a combination of photos, comments and location-based information with Facebook-style updates. This kind of microblogging is not to everyone's taste and receiving countless text messages would be wearing to say the least; there is also recent evidence that social networking sites are losing their popularity but nevertheless, there does appear to be an overwhelming human desire to be connected with those we care about and socialise with.

In Canada, Sweden, Austria and New Zealand, for example, blogs have been provided on official destination websites (Schmollgruber 2007; Thraenhart 2007). But blogs are not just growing in consumer to consumer (C2C) communications; it 
includes business to business (B2B), business to consumers (B2C), government to businesses (G2B) and government to consumers (G2C), but our knowledge is patchy so far and blogs often have a relatively short life span or shelf life which makes tracking more difficult. In terms of communication (as an internet function) the majority of travel blogs are $\mathrm{C} 2 \mathrm{C}$ particularly online diaries publishing personal stories and experiences. Such blogs exhibit the overwhelming human need to "belong", socially interact and share life experiences (Pan et al. 2007; Gretzel et al. 2007). There is an understandable worry that negative comments on UGC sites not backed up by evidence could damage tourism businesses and tourism destinations but many believe that travel blogs have very little impact, with many blogs confined to generalities of transport, climate, cuisine and such like (Wenger 2008; Carson 2008; Pan et al. 2007), although blogs in online travel communities do discuss more microdetails such as accommodation, restaurants and so on (Waldhör 2007). B2B blogs are often regarded as "knowledge" blogs or "expert" blogs with networking between tourism professionals. Often the information exchanged involves industry trends, market data, research and technical developments (Thraenhart 2007; Lew 2007; Oellrich and Bauhuber 2007; Price and Starkov 2006). B2C blogs (also referred to as classical corporate blogs) became popular for tourism organisations and enterprises as a way of promoting products and building customer relationships (Oellrich and Bauhuber 2007; Smudde 2005) These corporate blogs brighten and enliven corporate websites and may help to increase website traffic, although evidence is hard to come by. G2C blogs have similar aims to corporate blogs and often hire experienced and professional bloggers as "opinion leaders" (Price and Starkov 2006), while recently, destination blogs have engaged local people to provide information and in so doing make the information more trustworthy, for example, VisitFlorida (2008). Some state and regional tourism organisations in the USA are using paid or sponsored bloggers (see for example http://playinthecity.blogs.com and http://www.visitpa.com/) and some European destinations such as Amsterdam are also using this approach.

Tourism enterprises have also realised that blogging may be cheaper and possibly more effective than advertising and some researchers feel that blogs provide a new and novel way of helping to define a destination or corporate image, but not all customers will post comments on a corporate blog, far from it (Waldhör 2007; Pan et al. 2007; Choi et al. 2007; Douglas and Mills 2006). Some hotel companies have encouraged visitors to write comments on their hotel blogs with rewards such as discounts and vouchers (Price and Starkov 2006). But there are dangers of credibility - are the blogs written by real customers and travellers? (Litvin et al. 2007; Hotelmarketing.com 2007). Mack et al. (2008, p. 141) found that in terms of overall credibility "nothing beats traditional word-of-mouth" and blogs, whether corporate or personal, were perceived to be "significantly less trustworthy than traditional word-of-mouth". There is, however, scope for potential mischief, such as employees posing as real customers and providing negative comments on competitors, etc. (Litvin et al. 2007), although it is argued that obviously fake comments and reviews are readily spotted (Gobbi 2005; Schmollgruber 2007) and professional review sites such as tripadvisor.com employ editors to review contents and examine submissions. Blogs do, however, need to be interesting, entertaining, provide good information and good networking opportunities; otherwise they 
quickly wither and become worse than useless. Some travel blogs, for example, started with good intentions but the chore of regularly updating the web log often means that content remains static for months, which negates the whole purpose. Furthermore, some blogs are self-indulgent and little more than an online diary of questionable value. Such blogs generally go unnoticed and unvisited and quietly stagnate or disappear. Clearly a blog needs regular maintenance, updating and especially bright new content (Price and Starkov 2006). With hundreds of thousands of blogs each one needs a compelling reason to visit them and repeatedly visit them.

In product distribution the opportunities to use blogs for direct product distribution could be more limited (Buhalis 2001; Laws 2001). But tripadvisor.com for example, helps distribution with revenue generated by links to booking platforms and achievement of high click-through rates (Price and Starkov 2006) and virtual offices are being created (for example, www.virtualstatravel.com; Gaskell 2007). One other noticeable trend is a movement away from online travel agencies to direct customer involvement with supplier websites (hotels, airlines and other travel and tourism providers) (Etrip Travel Blog 2007). Such a trend was perhaps inevitable as consumers grew in experience and confidence in using the internet but this trend poses a major challenge to travel agencies.

Finally, blogs have a value for marketing management, management and marketing research. Clearly intensive use of blogs can be used for customer profiling, customer acquisition, customer engagement, brand awareness, brand reinforcement, reputation management and customer service (Laboy and Torchio 2007 and Dellarocas 2003). Blogs can also be used for analysing competitor strategies and market research (Litvin et al. 2007) and as an internal communication and knowledge management tool within a tourism organisation (Nacht 2007). But it is in the area of market research that perhaps blogs will have the greatest and most long-lasting impact (Bulkeley 2005). It is possible that blogs may reflect more genuine opinions and attitudes of tourists than more traditional market research although this needs to be thoroughly tested (Pan et al. 2007; Wenger 2008), while it may be that careful analysis of blogs enables tourism organisations and enterprises to assess "hard to reach" market segments or uncover unsuspected strengths and weaknesses of a destination or tourist organisation (Choi et al. 2007). But the challenge for market researchers and managers is how to search and visit the vast number of travel blogs in order to derive usable information?

\section{The problem of sourcing and extracting relevant blog content}

How to monitor the attitudes, opinions and satisfaction with tourism products is an ongoing problem for tourism organisations and enterprises. Can these attitudes be tracked over time, can they be reinforced and what attitudes need to be changed? Blogs might offer opportunities for addressing some of these issues. Carson (2008) in a pioneering study has identified word-of-mouth recommendations as a key source of trip planning information for a range of travel market segments, especially independent travel markets which includes backpackers and "grey nomads". Carson began his research study believing that blogs might be more representative of the 
real thoughts and feelings of tourists but there was a need to locate, extract and interpret blog content (Carson 2008, p. 112). Unfortunately there is no known published research on the type of tourist or traveller who writes blogs and what trip types and destination types are more likely to generate blog content (Carson 2008; Weber and Roehl 1999; Li and Buhalis 2005). Carson (2008) assessed the value of blog monitoring as a market research tool in Australia's Northern Territory. To locate the 99 blogs used in the research he had to view over 2,000 links. Carson found that the most likely bloggers were relatively young travellers on relatively long trips but he concedes these may equally be the most likely profile of visitors to the Northern Territory who happen to blog. Blog content was relatively shallow and provided little detail about expectations, satisfaction with tourist products or recommendations. He concluded that the costs of locating relevant blogs and analysing their content may not be justified for the purposes of assessing visitor attitudes to a destination but the range of markets is likely to grow over time.

Other researchers have pointed out not only the sheer time and energy needed to locate relevant blogs but also the imperative of addressing the usefulness of blogs at different stages in tourist consumer decision making, from developing awareness of the tourism product through to post-purchase evaluation (Mack et al. 2008).

One way forward may be "opinion mining" (as opposed to data mining) by using artificial intelligence, information retrieval and natural language processing (Pekar and $\mathrm{Ou}$ 2008). Such opinion mining could lead to automatic discovery, analysis and generalisation of tourism consumer views and opinions, especially via the automatic recognition of semantic relationships between tourism product features and attributes, and consumer opinions and satisfactions when consuming those products (provided, of course, that these consumers are minded to write their comments in a blog).

Finally, another way forward around this blog identification, trawling and extraction problem is the development of a "Blog Visualizer" to search the web for relevant blogs, collate the information and present it in a continuous presentation, perhaps in an audio-visual format and context (Sharda and Ponnada 2008; Celik and Elci 2006).

\section{Conclusion}

User generated content (UGC) can help to inform tourism and marketing managers, educate tourism consumers and facilitate tourism transactions. The value of UGC has perhaps been under-valued but there is no denying that a rich and varied stream of travel and tourism information is available online provided the information can be extracted, summarised and re-presented in an intelligible and relevant form to the decision makers who need it. Unfortunately research to date has failed to systematically identify the type of tourist or traveller who actually writes blogs and what types of trip and stays in destinations are more likely to generate meaningful UGC. Moreover, the time, energy, resources and costs required to locate relevant UGC and extract useful and meaningful information is currently too much at the present time. The search is now on for automated tracker systems perhaps utilising 
artificial intelligence. If that search is successfully completed tourism organisations, enterprises and tourists will have a potentially powerful new weapon in their decision-making armouries.

Open Access This article is distributed under the terms of the Creative Commons Attribution Noncommercial License which permits any noncommercial use, distribution, and reproduction in any medium, provided the original author(s) and source are credited.

\section{References}

Adam J, Cobos X, Liu S (2007) Travel 2.0: trends in industry awareness and adoption. New York University and PhoCusWright Inc., New York

Albert TC, Sanders WB (2003) e-Business marketing. Pearson Education, Upper Saddle River New Jersey

Beaumont C (2008) Tweet, tweet, here comes Twitter. The Telegraph, 12 April, p 21

Buhalis D (2001) Tourism distribution channels: practices and processes. In: Buhalis D, Laws E (eds) Tourism distribution channels. Practices, issues and transformations, 2nd edn. Tower, London, pp 7-32

Bulkeley W (2005) Marketers scan blogs for brand insights. Wall Str J, 23 June. http://online.wsj.com/ public/article/SB111948406207267049qs710svEyTDy6Sj732kvSsSdl_A_20060623.html?mod=blogs. Retrieved 16 April 2008

Carson D (2005) An overview of developing regional tourism using information communications technology. In: Marshall S, Taylor W, Yu X (eds) Encyclopaedia of developing regional communities with information and communication technology. Idea Group, Hershey PA

Carson D (2008) The blogosphere as a market research tool for tourism destinations: a case study of Australia's Northern Territory. J Vacat Mark 14(2):111-119

Celik D, Elci A (2006) Discovery and scoring of semantic web services based on client requirement(s) through a semantic search agent. Proceedings of the 30th annual international computer software and applications conference, September, pp 273-278

Choi SJ, Lehto XY, Morrison AM (2007) Destination image representation on the web: content analysis of Macao travel related websites. Tour Manag 28(1):118-129

Cobanoglu C (2006) An analysis of blogs as a teaching tool as perceived by hospitality management students. J Hosp Leis Sport Tour Educ 5(2):83-88

Crotts J (1999) Consumer decision making and prepurchase information search. In: Mansfield Y, Pizam A (eds) Consumer behavior in travel and tourism. Haworth Press, Binghamton, NY, pp 149-168

Dellaert B (2000) Tourists' valuation of other tourists' contribution to travel web sites. In: Fesenmaier D, Klein S, Buhalis D (eds) Proceedings of the 7 th conference on information and communication technologies. Springer-Verlag, Vienna, pp 293-302

Dellarocas C (2003) The digitization of word of mouth: promise and challenges of online feedback mechanisms. Manag Sci 49(10):1407-1424

Douglas AC, Mills JE (2006) Loggging brand personality online: website content analysis of Middle Eastern and North African destinations. In: Hitz M, Sigala M, Murphy J (eds) Information and communication technologies in tourism 2006. Springer, New York

eMarketer (2007) UK Online travel: travellers are sharing experiences online', 25 June. http:// www.emarketer.com/Article.aspx?id=1005067andsrc=article2_newsltr. Retrieved 17 April 2008

Etrip Travel Blog (2007) Online distribution channels on the move, 26 April. http://blog.etrip.nl/2007/04/ 26/online-distribution-channels-on-the-move/. Retrieved 16 April 2008

Ellion (2007) Web 2.0 and the travel industry: practical strategies for exploiting the social media revolution. White paper. http://www.ellion.co.uk/sectors/travel/index.php. Retrieved 17 April 2008

Gaskell K (2007) Virtual tourism takes off in second life. http://www.news.com.au/travel/story/ 0,23483,21982063-5012740,00.html. Retrieved 17 April 2008

Gitleson R, Kerstetter D (1994) The influence of friends and relatives in travel decision making. J Travel Tour Mark 3(3):59-68

Gobbi J (2005) Sponsored blogs and the conflict of interests. Zirma-travel, communications and mobilities, 4 August. http://www.zirma.com/blog/2005/08/04/sponsored-blogs-and-a-the-conflictof-interests/. Retrieved 16 April 2008 
Gretzel U, Yoo KH, Purifoy M (2007) Online travel review study: role and impact of online travel reviews. Laboratory for Intelligent Systems in Tourism, Texas A \& M University. www. tripadvisor.com/pdfs/OnlineTravelReviewReport.pdf. Retrieved 17 April 2008

Hennig-Thurau T, Gwinner K, Walsh G, Gremler D (2004) Electronic word-of-mouth via consumeropinion platforms: what motivates consumers to articulate themselves on the internet? J Interact Mark 18(1):38-52

Hotelmarketing.com (2007) User generated comments: travel brands most at risk', 31 July. http://www. hotelmarketing.com/index.php/article/070731_user_generated_comments_travel_brands_most_at_risk/. Retrieved 17 April 2008

Johnson T, Kayne B (2003) Wag the blog: how reliance on traditional media and the internet influence credibility perceptions of weblogs among blog users. Journal Mass Commun Q 11(3):622-642

Kelleher T, Miller BM (2006) Organizational blogs and the human voice: relational strategies and relational outcomes. J Comput Mediat Commun 11(2). http://jcmc.indiana.edu/vol11/issue2/ kelleher.html. Retrieved 17 April 2008

Laboy F, Torchio P (2007) Web 2.0 for the travel marketer and consumer: a white paper. E-site Marketing and the International Association of Online Communicators. http://www.esitemarketing. com/web2-travel-marketing.php. Retrieved 16 April 2008

Laws E (2001) Distribution channel analysis for leisure travel. In: Buhalis D, Laws E (eds) Tourism distribution channels. Practices, issues and transformations, 2nd edn. Tower, London, pp 53-72

Lew A (2007) Why don't we blog? University faculty blogging about travel \& tourism. Tourism Place, 30 June. http://tourismplace.blogspot.com/2007/05/why-dont-we-blog-university-faculty.html. Retrieved 17 April 2008

Li L, Buhalis D (2005) Predicting internet usage for travel bookings in China. In: Frew AJ (ed) Information and communication technologies in tourism proceedings of the international conference, Innsbruck, Austria. Springer, New York and Vienna, pp 429-439

Litvin S, Goldsmith RE, Pan B (2007) Electronic word-of-mouth in hospitality and tourism management. Tour Manag. http://www.ota.cofc.edu/pan/. Retrieved 17 April 2008

Liu S (2005) A theoretic discussion of tourism e-commerce. Proceedings of the 7th international conference on electronic commerce. ACM Press, New York

Lueg C (2001) Corporate communications and the rise of the network society. Int J Media Manag 3(3):161-166

Mack RW, Blose J, Pan B (2008) Believe it or not: credibility of blogs in tourism. J Vacat Mark 14(2):133-144

Nacht R (2007) Blogs, effective tools for internal communications, 26 January. http://www.realblogging.com/ effective-blog-marketing/blogs-effective-tools-internal-communications-part-iv. Retrieved 17 April 2008

Newhagen J, Rafaeli S (1996) Why communication researchers should study the internet: a dialogue. J Comput Mediat Commun 46(1):4-13

O'Reilly T (2005) What is web 2.0: design patterns and business models for the next generation of software. http://www.oreillynet.com/pub/a/oreilly/tim/news/2005/09/30/what-is-web-20.html. Retrieved 16 April 2008

Oellrich J, Bauhuber F (2007) Inside of a blog, background and thoughts from the touristic blog Tourismus-zukunft.de. Blogs in tourism conference, Kitzbühel, 12 July

Österreich Werbung (2007) Web 2.0 im internet: Onlinebefrafung unter deutschen Österreich-Urlaubern. http://www.austriatourism.com/scms/media.php/8998/2007E_Web20_summary.pdf. Retrieved 14 April 2008

Pan B, MacLaurin T, Crotts J (2007) Travel blogs and their implications for destination marketing. J Travel Res 46(1):35-45

Pekar V, Ou S (2008) Discovery of subjective evaluations of product features in hotel reviews. J Vacat Mark 14(2):145-155

Playinthecity.blogs.com (2008) http://playinthecity.blogs.com/. Retrieved 12 April 2008

Price J, Starkov M (2006) Building a blog strategy in hospitality: grow customer relationships and direct online revenue. http://www.hospitalitynet.org/news/4026867.html. Retrieved 16 April 2008

Rabanser U, Ricci F (2005) Recommender systems: do they have a viable business model in e-tourism. In: Frew A (ed) Information and communication technologies in tourism in 2005. Proceedings of the enter conference in Innsbruck, Austria, 2005, Springer, Vienna, pp 160-171

Reactive (2007) Web 2.0 for the tourism and travel industry: a white paper. Reactive Media Pty Ltd. http://blogs.reactive.com/RequestWhitepaper.aspx. Retrieved 17 April 2008 
Sarks G (2007) Consumer generated content in travel: a roadmap for bringing consumers into the conversation. Web-seminar presentation, 16 April. Compete, Inc

Schmollgruber K (2007) Fake travel reviews are no issue-interview with Ian Rumgay from tripadvisor, 23 April. http://passionpr.typepad.com/tourism/2007/04/fake_travel_rev.html. Retrieved 17 April 2008

Schwabe G, Prestipino M (2006) How tourism communities can change travel information quality. Proceedings of the 13th European conference on information systems (ECIS) 2005. www.ifi.uzh.ch/ im/fileadmin/user_upload/personen_downloads/TheoriesCommunities2.pdf. Retrieved 16 April 2008

Senecal S, Nantal A (2004) The influence of online product recommendations on consumers' online choices. J Retail 80:159-169

Sharda N, Ponnada M (2008) Tourism blog visualizer for better tour planning. J Vacat Mark 14(2): $157-167$

Sifry D (2007) The state of the live web, April 2007. http://www.sifry.com/alerts/archives/000493.html. Retrieved 16 April 2008

Smudde P (2005) Blogging, ethics and public relations: a proactive and dialogic approach. Pubic Relat Q 50(3):34-38

Technorati.com (2008) http://technorati.com/about. Retrieved 16 April 2008

Thraenhart J (2007) Destinations and the benefits of blogging, 30 July. http://jensthraenhart.com/cblog/ archives/256-Destinations-and-the-benefits-of-blogging.html. Retrieved 17 April 2008

VisitFlorida (2008) http://floridians.visitflorida.com/getaways/g/cocoa_beachs_charms.php. Retrieved 17 April 2008

Visitpa.com (2008) http://www.visitpa.com/. Retrieved 17 April 2008

Wang Y, Fesenmaier DR (2006) Identifying the success factors of web-based marketing strategy: an investigation of convention and visitors bureaus in the United States. J Travel Res 44(3):239-249

Wang Y, Yu Q, Fesenmaier DR (2002) Defining the virtual tourist community: implications for tourism marketing. Tour Manag 23:407-417

Weber K, Roehl WS (1999) Profiling people searching for and purchasing travel products on the world wide web. J Travel Res 37:291-298

Werthner H, Ricci F (2004) E-commerce and tourism. Commun ACM 17(12):101-105

Wenger A (2008) Analysis of travel bloggers' characteristics and their communication about Austria as a tourism destination. J Vacat Mark 14(2):169-176

Waldhör K (2007) 'etBlogAnalysis-analyzing touristic webblogs and forums using statistical and computer linguistic methods for quality control', presented at the 'blogs in tourism' conference, Kitzbühel, 12 July. Krems Research Forschungsgesellschaft mbH 